\section{Regional Survey of Croydon and District}

THE Croydon Natural History and Scientific Society commenced in 1913 a regional survey of Croydon and district. The first fruits of this task were published in 1936, as an atlas consisting of a number of maps prepared by members, in a looseleaf binder. Since then, several further parts have been issued, the latest being the fourth, while a fifth is in preparation. The new part contains a handcoloured reduced facsimile of the rare first geological map of Surrey (William Smith, 1819), a chart of the Glacial Period, and a map showing the distribution of Iron Age sites and finds in the Croydon district. Eash item is accompanied by a sheet of explanatory text, and there is also a note on the Roman occupation of the district. The members of the Society deserve congratulations both for their original concept and the way in which it is being carried out. The chairman of the Regional Survey Committee is Mr. C. C. Fagg, 58 Birdhurst Road, South Croydon, Surrey.

\section{Frank B. Jewett Fellowship Awards}

The American Telephone and Telegraph Co. has awarded five Frank B. Jewett fellowships, as follows : Dr. Stanley Deser, a graduate of Brooklyn College and of Harvard University, for research on the quantum field theory, specifically meson processes, at the Institute for Advanced Study, Princeton; Thomes Fulton, a graduate of Harvard University, for the investigation of problems in theoretical nuclear physics and the quantum theory of fields; Stanley L. Miller, a graduate in chemistry of the University of California, for the continuation of his research at the University of Chicago on the preparation of organic compounds by an electric discharge through a mixture of hydrogen, methane and ammonia, in an attempt to imitate possible conditions in the early history of the earth ; Dr. Roger G. Newton, a graduate of Harvard University, who as a Jewett Fellow last year at the Institute for Advanced Study, Princeton, has been investigating the problem of a connexion between the quantum field theories and detailed behaviour of nuclei and their effect on surrounding electrons, and plans to do research on high-energy approximations in the quantum field theory; Dr. Richard Scott Pierce, a graduate of the California Institute of Technology, who was working last year as a Jewett Fellow at Harvard University on the analysis of automata and latticeordered rings, and plans to continue his work on the mathematics of automatic machinery and algebraic studies with applieations to topology and analysis. These fellowships, which are awarded by a committee from the Bell Telephone Laboratories, are given for research in the fundamental physical sciences by those who have recently received $a$ doctorate or are about to receive one. The stipend is 4,000 dollars to the recipient and 1,500 dollars to the institution at which he elects to conduct his research.

\section{Congress on Photobiology at Amsterdam}

THE Comité International de Photobiologie, formerly known as the Comité International de la Lumière, will hold a congress in Amsterdam at the Koninklijk-Instituut voor de Tropen, 63 Mauritskade, di ring August 23-28. The aims of the Committee are the stimulation of scientific research in the physics, chemistry and climatology of ultra-violet, visible and infra-red radiations as they pertain to biology and the study of the effects and applications of these radiations in biology and medicine. At present there are three sections, with presidents as indicated, covering the following branches of the subject: medicine (Dr. A. L. de Groot, of Rotterdam) ; biology (Dr. J. B. Thomas, of Utrecht); and the physics, chemistry and climatology of radiation, including methods of measurement (Prof. B. Rajewsky, of Frankfurt). Discussions will be held on a sectional basis, and, in addition to the above three sections, others may be formed at the congress if the papers warrant it. There will also be three general symposia during the congress as follows: photoperiodism in plants and in animals; the effects of non-ionizing radiation on genetic elements of cells; and the fundamental effects of non-ionizing radiation on skin. The official language of the congress will be French, but English and German will also be used. Application forms and further information can be obtained from the secretariat of the congress at the Radiologisch Laboratorium, Wilhelminagasthuis, Amsterdam.

\section{Surface-Active Detergents : Congress in Paris}

A congress on surface-active agents and detergents, organized by the French body known as 'Tramagras' with the help of the Institut des Corps Gras and other professional associations, will be held in Paris at the Sorbonne during August 30-September 3. The congress is under the auspices of the United Nations Food and Agriculture Organization, and is intended to bring together persons from all over the world who are interested in the subject. The official languages will be English and French, though translating services and other assistance will be provided for those unable to express themselves directly in either of these two languages. The congress will discuss the scientific, technical, industrial and economic aspects of the subject, and it is hoped to establish a permanent international committee to maintain the exchange of information and to organize further congresses. There are various forms in which persons may participate in the deliberations, the simplest being as an associate member (3,000 franes) or active participating member (5,000 francs). Those wishing to participate must enrol before June 15, application forms and further information being obtainable from the secretariat of the congress at 70 Champs-Elysées, Paris $8^{\mathrm{e}}$.

\section{Announcements}

THE following appointments have been made in The Queen's University of Belfast: N. Stephens, to be lecturer in geography; E. R. Redfearn, to be lecturer in biochemistry; A. G. Smith, to a senior research post in the Department of Botany to work on Quaternary ecology ; Dr. B. L. Moiseiwitsch, to be a supernumerary lecturer in applied mathematics.

THE firm of Quickfit and Quartz, Ltd., of Stone, Staffs, has presented $£ 50$ to Norwood Technical College, London, to provide an annual $£ 2$ prize for the best student of advanced chemistry. This money has been given in recognition of the work of Dr. J. T. Stock and Mr. M. A. Fill, both of the College, who have designed a miniature organic chemistry laboratory (see Nature, April 17, p. 715), now being made by the firm.

IN the article entitled "Mechanism of Anionotropy" in Nature of May 8, p. 863, Fig. 1, the legend on the abscissa should read "Time $\left(10^{3} \mathrm{~min}\right.$.)" instead of "Time (min.)". 